\title{
Financial Analysis of an Australian Department Company Based on 3 Financial Models
}

\author{
Ke Lyu \\ University of Wollongong Australia, Wollongong, Australia \\ Email: akesq@outlook.com
}

How to cite this paper: Lyu, K. (2021). Financial Analysis of an Australian Department Company Based on 3 Financial Models. Open Journal of Business and Management, 9, 858-865. https://doi.org/10.4236/ojbm.2021.92045

Received: February 22, 2021

Accepted: March 28, 2021

Published: March 31, 2021

Copyright (c) 2021 by author(s) and Scientific Research Publishing Inc. This work is licensed under the Creative Commons Attribution International License (CC BY 4.0).

http://creativecommons.org/licenses/by/4.0/

\begin{abstract}
In the modern economic market, it is necessary for investors and decision makers to evaluate the financial situation of enterprises. For the managers, the analysis of financial statements can help to judge the development prospects of enterprises, so as to manage and make decisions on the future development direction. And investors can get the accurate business results of the enterprise this year, which has important reference significance for whether to invest in the enterprise. The purpose of this report is to analyze the Australian department store, Myer, its financial status and provide investment advice to potential investors and operating suggestions to its managers. Three financial models were used to analyze the value of Myer, which are comparable analysis (COMPS), dividend discount model (DDM) and discount cash flow (DCF) models respectively.
\end{abstract}

\section{Keywords}

Financial Report, Comparable Analysis, Dividend Discount Model, Discounted Cash Flow Valuation, SWOT

\section{Introduction}

Myer, an Australia's largest department store group, has been synonymous with fashion for more than 100 years. It has 67 stores in Australia, 12,500 team members and 54,000 shareholders, and the store has more than 130 million customers visit every year. The loyalty program MYER ONE has more than 5 million members (Myer Official Website). The offers include 11 core product categories: Women's Wear, Men's Wear, Beauty, Home Supplies and Electronics, etc. After a few years of private equity investment, Myer's business returned to the public after the listing of ASX in late 2009. The initial public offering was the largest in 2009 , and the shares were subscribed at a follow-up price of $\$ 4.10$ per share. The 
market value at issue was 2768 million (DatAnalysis Premium). In the past few years, Myer's sales had a good performance, total sales in the 2013 fiscal year with more than US\$3.1 billion, and total sales in 2016 exceeded US $\$ 3.2$ billion.

This report analyzes Myer's financial status by using COMPS, DDM and DCF models respectively. The COMPS model mainly compares the data of Myer with other two retailing companies-JB-Hifi and Woolworths. DDM and DCF models evaluate Myer by analyzing the dividends and free cash flow predicted for the next five years. Then the SWOT analysis is provided in order to value the circumstance of the company. In the end, the valuation and investment recommendation are presented.

\section{Valuation}

\subsection{Pros and Cons of Each Valuation Model}

The most common way to measure company value is to use comparable analysis. This method specifically refers to finding a group of companies that compare with the target company and drawing an average based on their value to predict future value. The comparable analysis is often referred to as "COMPs" (Penman, 2013: p. 76). This report chooses two similar retail companies, JB Hi-Fi and Woolworths to calculate the $\mathrm{P} / \mathrm{E}, \mathrm{P} / \mathrm{B}, \mathrm{P} / \mathrm{S}$ respectively. Then apply these multiples to the corresponding measures for the target to get that firm's value. This method is widely used and applied in some circumstances. While it also has drawbacks and uncertainties, for example, it is uncertain how to weigh based on price-to-income, book value, free cash flow and EBITDA. These may result in a large difference in valuations. Besides, The Investment bankers might use the prices in past comparable IPO transactions instead of the current comparable prices (Penman, 2013: p. 77). If market mispricing the COMPs, it will also make erroneous pricing of IPO. Thus the company may lose value. Meanwhile, the Dividend Discount Model (DDM) is a method for assessing a company's stock price based on the theory of the company's stock value. Since the DDM model based on the net present value of future dividends, the concept of Dividend Discount model is easy to understand and forecast accurately values, and they are usually fairly stable in the short term. However, dividend payments are not related to value in the short term dividend forecasts, and ignore the capital gain portion of earnings. In addition, it is difficult to calculate the end of the shorter period (Penman, 2013: p. 114). The concept of Discount Cash Flow is about the value creation in a business and translating into a valuation (Penman, 2013: p. 119). The DCF model focus on the cash flow specifically refers to the company's investment and business activities. The advantage of the DCF model is cash flow is 'real' and working according to accounting standards and the net present value method. However, free cash flow does not measure value added in the short term, and the value obtained does not match the value of the abandonment. Furthermore, free cash flow does not accurately identify other value, such as investments which are considered the loss of value. Companies often increase free 
cash flow by reducing investment. In this case, Myer's growth in previous years has been negative, but it was steadily rising. Myer as a large retail mall, has invested in joining a number of merchants in the past year, to increase the cash flow. This report will use COMPS, DDM, and DCF models to analyze and predict the development trend of Myer company in the next five years.

\subsection{Method of Comparables (COMPS)}

Firstly, identified the target company of the analysis. This reporter selected two retail companies related to Myer's value, JB Hi-Fi and Woolworth. Secondly, according to DatAnalysis, the $\mathrm{P} / \mathrm{E}, \mathrm{P} / \mathrm{B}$ and $\mathrm{P} / \mathrm{S}$ in the financial statements of the two companies can be gathered, and the average of each indicator is calculated (see Table 1). Price to earning ratio is the most concerned index for investors when they invest in stocks (Ye, 2016). Basu (1977) found that the stocks with low $\mathrm{P} / \mathrm{E}$ ratio brought higher returns than those stocks with high $\mathrm{P} / \mathrm{E}$ ratio, which called P/E effect. In terms of the P/E ratio and the company's performance, Fuller et al. (1993) pointed that $\mathrm{P} / \mathrm{E}$ ratio was positively correlated with the future earnings of the companies.

Finally, the sales, earnings and book value are known, according to Myer's annual report (see Table 2). The average Multiple for Comparables calculated in Table 2 are multiplied by Myer's sales, earnings and book values. The final value of the Averager valuation is Myer's target market value. While Myer actual valuation on 2017 was $\$ 303,870,000$ less than the average valuation. Therefore, the value of Myer is lower than another same type of retail companies. JB Hi-Fi and Woolworth are more irreplaceable than Myer, and food and appliances are irreplaceable. As a department store, Myer has more competitors in the same type of malls, such as David Jones and Westfield, which affected its market value.

Table 1. P/E \& P/B of comparables in 2017.

\begin{tabular}{cccc}
\hline Comparable companies & JB Hi-Fi & Woolworths & Average \\
\hline Year & 2017 & 2017 & 2017 \\
Price to Earnings & 12.51 & 23.12 & 17.815 \\
Price to Book Value & 3.13 & 3.33 & 3.2300 \\
Price to sale & 49.93 & 43.24 & 46.59 \\
\hline
\end{tabular}

Table 2. Sales, earnings \& book value of comparables.

\begin{tabular}{cccc}
\hline & Average Multiple for Comparables & Myer's number & Myer's valuation \\
\hline Sale \$ & 46.59 & $3,201,427$ & $149,154,483.9$ \\
Earnings \$ & 17.815 & $10,430,000$ & $185,810,450$ \\
Book value \$ & 3.23 & $460,211,000$ & $1,486,481,530$ \\
Average valuation \$ & & & $607,148,821.3$ \\
\hline
\end{tabular}




\subsection{Dividend Discount Model (DDM)}

$($ CAPM $)$ Return on equity $=2.3525 \%+2(7 \%-2.3525 \%)=0.1165 / 11.65 \%$

From Table 3, Myer's expected dividend growth rate in 2018, 2020 and 2022 are $0 \%,-28.32 \%,-22.42 \%$ respectively. Therefore the changing of expected dividend will follow the negative growth rate in future. In the calculation of present value of expected dividend, 2022 (Year 5) which is the terminal value would based on the value of a perpetuity. Therefore, total present value of expected dividend which also calls as value of equity is $\$ 0.1406$ per share. Since the share price of Myer on 07/17 is $\$ 0.76$, the value acquired from the Myer's dividend discount model was lower than July of 2017 trading price of shares, therefore, the value of Myer's Equity was overvalued.

\subsection{Discounted Cash Flow Valuation}

The analysis of discounted cash flow is a method of valuing equity by estimating the cash flow generated by the company's investment and operating activities, and subtracting the value of the net debt (Penman, 2013: p. 115). Since the 2018 fiscal year has not yet ended and the annual report has not been published, the calculations and analysis in this report is based on the 2017 annual report of Myer. In this report, the way to forecast the free cash flow for the next five years is to find the free cash flow in 2017 through Myer's annual report, and predict the growth rate of free cash flow through analyzing the past five-year growth rate. Then calculate the corresponding free cash flow from 2018 to 2022. The following calculations are the corresponding discount rate calculated by WACC.

$\mathrm{Rd}=$ can be estimated as interest expense/total debt $=1,094,000 / 143.37 \mathrm{mil}-$ lion $=0.0076$

$$
\begin{aligned}
& \mathrm{Re}=\mathrm{CAPM}=0.116475 \\
& \mathrm{Tc}=\text { company's corporate tax rate }=30 \% \\
& \mathrm{D}=\text { market value of debt }=14.337 \text { billion } \\
& \mathrm{E}=\text { equity market value }=303.87 \text { million } \\
& \mathrm{WACC}=0.0809=\text { discount rate }
\end{aligned}
$$

\begin{tabular}{|c|c|c|c|c|c|c|c|c|}
\hline \multicolumn{2}{|c|}{$\begin{array}{l}\text { Myer's Dividend Discount } \\
\text { Model (5 years forecast) }\end{array}$} & \multirow{2}{*}{$\begin{array}{c}\text { Y1 } \\
\text { Jul-18 }\end{array}$} & \multirow{2}{*}{$\begin{array}{c}\text { Y2 } \\
\text { Jul-19 }\end{array}$} & \multirow{2}{*}{$\begin{array}{c}\text { Y3 } \\
\text { Jul-20 }\end{array}$} & \multirow{2}{*}{$\begin{array}{c}\text { Y4 } \\
\text { Jul-21 }\end{array}$} & \multirow{2}{*}{$\begin{array}{c}\text { Y5 } \\
\text { Jul-22 }\end{array}$} & \multicolumn{2}{|c|}{$\begin{array}{l}\text { Myer's Dividend Discount Model } \\
\text { (5 years forecast) }\end{array}$} \\
\hline Year & Jul-17 & & & & & & Year & Jul-17 \\
\hline DPS & $\$ 0.05$ & $\$ 0.05$ & $\$ 0.05$ & $\$ 0.04$ & $\$ 0.03$ & $\$ 0.02$ & DPS & $\$ 0.05$ \\
\hline Dividend Growth Rate & & $0 \%$ & $0 \%$ & $-28.32 \%$ & $-28.32 \%$ & $-22.42 \%$ & Dividend Growth Rate & \\
\hline Discount Rate $(1.1165)^{t}$ & & $111.65 \%$ & $124.65 \%$ & $139.17 \%$ & $155.38 \%$ & $173.48 \%$ & Discount Rate $(1.1165)^{t}$ & \\
\hline $\begin{array}{l}\text { Present value of Expected } \\
\text { dividend to } 2022\end{array}$ & & $\$ 0.0448$ & $\$ 0.0401$ & $\$ 0.0258$ & $\$ 0.0165$ & $\$ 0.0134$ & $\begin{array}{l}\text { Present value of Expected } \\
\text { dividend to } 2022\end{array}$ & \\
\hline $\begin{array}{l}\text { Total PV of expected } \\
\text { dividend per share }\end{array}$ & $\$ 0.1406$ & & & & & & $\begin{array}{l}\text { Total PV of expected } \\
\text { dividend per share }\end{array}$ & $\$ 0.1406$ \\
\hline
\end{tabular}

Table 3. Myer's DDM model (5 years forecast). 
Since Myer's free cash flow growth rate has been negative constantly, the sustained growth rate of free cash flow in this report is predicted to be $-2.92 \%$, the same as the estimated growth rate in 2022. Therefore, the calculation of whole DCF is presented below.

From Table 4, Myer's free cash flow growth rate remains negative, but it is worth noticing that the growth rate shows a rising trend. This demonstrates that although Myer's free cash flow has been declining over the past five years and the next five years, the decline has gradually tended to be flat, and Myer's free cash flow may bottom out in the future to show an upward trend. In the DCF analysis, it will perform well when the positive free cash flow is generated by the investment model increases at a fixed rate. In the case of Myer, these data are eligible. Therefore the DCF analysis is useful for Myer company. The free cash flow is a contradictory value-added measure because companies need to increase their investment in order to increase their value. As a causal effect, cash flow will decrease. The more future investment for company, the more predictions will be needed to capture these advanced inflows. In recent years, Myer's cash flow reduction may be due to the increasing in investment. According to data provided by DatAnalysis Premium, the Myer's net cash investing in 2016 was 58.25 million dollars, and there was a significant increase in 2017, which was twice the value of 2016. This explains that Myer has decreased free cash flow by increasing investment, thereby adding value to the company, but taking on more liability. It takes Myer longer to obtain cash inflows. This investment is considered as "not good". Based on the historical data on DatAnalysis Premium, the market value and dividend of Myer company are declining. Therefore, Myer's valuation is not optimistic.

Table 4. Myer's DCF Model (5 years forecast in million).

\begin{tabular}{|c|c|c|c|c|c|c|}
\hline Myer's DCF Model ( 5 years forecast) & & Y1 & Y2 & Y3 & Y4 & Y5 \\
\hline Year & $2017(\$ \mathrm{~m})$ & $2018(\$ \mathrm{~m})$ & $2019(\$ \mathrm{~m})$ & $2020(\$ \mathrm{~m})$ & $2021(\$ \mathrm{~m})$ & $2022(\$ \mathrm{~m})$ \\
\hline Free cash flow & $\$ 77.00$ & $\$ 65.43$ & $\$ 56.72$ & $\$ 50.18$ & $\$ 46.89$ & $\$ 45.52$ \\
\hline Growth rate & & -15.035 & $-13.31 \%$ & -11.535 & $-6.56 \%$ & $-2.92 \%$ \\
\hline Discount rate $(1.0809)^{t}$ & & $108.09 \%$ & $116.83 \%$ & $126.29 \%$ & $136.5 \%$ & $147.55 \%$ \\
\hline $\mathrm{PV}$ of $\mathrm{CF}$ & & $\$ 60.53$ & $\$ 48.5461$ & $\$ 39.7331$ & $\$ 34.3496$ & $\$ 30.8493$ \\
\hline Total PV to 2022 & $\$ 214.0081$ & & & & & \\
\hline $\mathrm{CV}$ & & & & & & $\$ 401.35$ \\
\hline Present value of $\mathrm{CV}$ & $\$ 272.01$ & & & & & \\
\hline Enterprise value & $\$ 486.02$ & & & & & \\
\hline Book value of net debt & $\$ 113$ & & & & & \\
\hline Value of equity & $\$ 373.0195$ & & & & & \\
\hline Share outstandings & 821.267587 & & & & & \\
\hline Value per share & $\$ 0.4542$ & & & & & \\
\hline
\end{tabular}




\section{SW0T Analysis}

SWOT Analysis can help Myer company to discover the new opportunity in the well-performance area, to plan the long-term investment and expand the business size. Moreover, understanding the business's weakness and threats, Myer can manage the lower competitive and profitable field, to design the business strategy to reform the uncompetitive business. By using the SWOT analysis, Myer's strengths, weakness, opportunity and threats will be identified.

1) Strength

According to Myer Annual Report (2017: p. 3), over 70 percent of sales are made with "Myer one" loyalty card. It can enable Myer to clearly understand their most valuable customers by direct communication. Therefore, Myer can scale up and down the products based on the data from "Myer one" loyalty card, to satisfy the product's demand condition in the market, and improve the profit of business.

2) Weakness

For the Myer's weak financial performance, it was responsible that Myer has closed and has not renewed the leases for 4 stores. Even the fact that Myer has focused on the online shopping and provide the investment to expand the business in online shop, the growth of online sale was unable to offset the loss of sale from closed stores in short term. Therefore, Myer's financial performance has been affected by internal strategy.

3) Opportunity

Providing the international online shopping platform, Myer can obtain the huge potential return and advertise the Myer Brand name toward global. There are various famous online stores in the world such as Amazon and Ebay. Myer has provided the online shopping platform within Australia and New Zealand. If Myer continues to invest and expand the online shopping platform toward global, it can enjoy the stronger sales growth and higher demand of goods, to acquire positive future cash flow.

4) Threat

For threat of substitution, Myer major product substitution is David Jones which has similar categories of product, upmarket department store and provides premium goods. Myer and David Jones are competing on price and superior benefits which can attract the specific customers. Moreover, reducing their ranges of brand can help them focus on specific customer segments. It reflected that Myer and David Jones both focused on growth of profit through different strategies. Therefore, the threat of substitutes for Myer has become more severe if David Jones lower the price of goods and the switching cost of Myer is decreased.

\section{Conclusion and Recommendation}

In general, this report evaluates Myer based on Myer's past performance and predictive value of future performance. Based on the COMPS, DDM, and DCF 
models, it analyzed Myer's free cash flow and analyzed whether discounted cash flow analysis is applicable for Myer. It can use those forecasts to analyze the possible incremental growth of its value for the next five years.

A clear view can be drawn from the above analysis. Myer has not been a good choice for investors in recent years. As a for-profit company, Myer said that the future agenda will prioritize investment and believe that these investments will enable itself to achieve sustainable and sustainable profitability in an increasingly unpredictable future environment. From the DCF point of view, the growth rate of free cash flow has been negative in the past years and the next five years as well, which means that the investment has increased. From the perspective of Myer company, this investment does not increase the company value and the stock value. Myer needs a long time to achieve the expected cash inflow. Therefore, for an investor buying Myer stock at this time is not a good choice. In addition, as outlined in the first half of 2017 and the third quarter of 2017, during this period, Myer's performance was lower than expected. Although it has continually improved its business performance, Myer company has confirmed a depreciation of $\$ 38.8$ million from the book value of the business (2017 Myer Annual Report). The ultimate goal of company's operation is to create value (Ye, 2016). Lapaport (2002) pointed that company's value is composed of three dimensions: growth, profit and risk. In order to achieve the value creation, profit should not be the only core target of the company's operation. Only by completing the triple management tasks of growth, profit and risk, can the company achieve the long term development (Tang \& Du, 2004). Therefore, for Myer, it is important to adjust strategy to cope with the changeable market competition, and analyze the current and future risks and make preparations well. Besides, it is also important to be aware of the strategy and situation of its competitors. Make sure that it will develop and invest in the online service and offline business. As the largest department store group in Australia, Myer has strong support and its future development can be expected and managed.

As a result, based on COMPS, DDM and DCF models, Myer's shareholder should sell their stock as soon as possible, and the potential investor should not buy the Myer's stock at this moment.

\section{Conflicts of Interest}

The author declares no conflicts of interest regarding the publication of this paper.

\section{References}

Basu, S. (1977). Investment Performance of Common Stocks in Relation to Their Price-Earning Ratios: A Test of the Efficient Market Hypothesis. Journal of Finance, 32, 63-82. https://doi.org/10.1111/j.1540-6261.1977.tb01979.x

DatAnalysis Premium.

https://datanalysis.morningstar.com.au/af/dathome?xtm-licensee=datpremium 
Fuller, R. J., Huberts, L. C., \& Levinson, M. (1993). Return to P/E Strategies, Higgledy-Piggedy Growth, Analyst's Forecast Errors, and Ommited Risk Factors. Journal of Portfolio Management, 19, 13-24. https://doi.org/10.3905/jpm.1993.13

Lapaport, A. (2002). Creating Shareholder Value. Kunming: Yunnan People's Publishing House.

Myer Investor and Media Centre (2017). 2017 Myer Annual Report.

https://investor.myer.com.au/Reports/?page=Annual-Reports

Myer Official Website. https://www.myer.com.au/

Penman, S. H. (2013). Financial Statement Analysis and Security Valuation (5th ed.). United States: McGraw Hill.

Tang, G., \& Du, F. (2004). On the Three Dimensional Balanced Strategic Management of Enterprise Growth and Profit Risk. Accounting Research, No. 11, 31-37.

Ye, H. (2016). Is P/E Ratio an Effective Indicator for Investment Decision? An Empirical Analysis Based on Financial Position of Listed Companies in GEM. Accounting and Economic Research, 26, 41-51. 